\title{
Long non-coding RNAs: a rising biotarget in colorectal cancer
}

\author{
Jian Luo ${ }^{1, *}$, Jian $\mathbf{Q u}{ }^{2,}{ }^{*}$, Dong-Kai Wu${ }^{3}$, Zhi-Li Lu ${ }^{4}$, Yue-Sheng Sun ${ }^{5}$ and Qiang $\mathbf{Q u}{ }^{1}$ \\ ${ }^{1}$ Department of Pharmacy, Xiangya Hospital, Central South University, Changsha, P. R. China \\ 2 Department of Pharmacy, The Second Xiangya Hospital, Central South University, Institute of Clinical Pharmacy, Central \\ South University, Changsha, P. R. China \\ ${ }^{3}$ Department of Cardiothoracic Surgery, Xiangya Hospital, Central South University, Changsha, P. R. China \\ ${ }^{4}$ Department of Pathology, The Affiliated Cancer Hospital of Xiangya School of Medicine, Central South University, Changsha, \\ P. R. China \\ ${ }^{5}$ Department of General Surgery, The Third Clinical College of Wenzhou Medical University, Wenzhou People's Hospital, \\ Wenzhou, P. R. China \\ * These authors have contributed equally to this work
}

Correspondence to: Qiang Qu, email: quaiang2015@hotmail.com

Keywords: colorectal cancer, long non-coding RNAs, invasion, epithelial-mesenchymal transition

Received: November 01,2016 Accepted: January 09,2017 Published: January 18, 2017

\section{ABSTRACT}

Colorectal cancer (CRC) is a common gastrointestinal cancer, with a high incidence and high mortality. Long non-coding RNAs (IncRNAs) are involved in the development, invasion and metastasis, early diagnosis, prognosis, the chemoresistance and radioresistance of CRC through interference with mRNA activity, directly combining with proteins to regulate their activity or alter their localization, influencing downstream gene expression by inhibiting RNA polymerase and regulating gene expression as competing endogenous RNAs. Recent progress in next generation sequencing and transcriptome analysis has revealed that tissue and cancer-type specific IncRNAs could be useful prognostic markers. Here, the CRC-associated InCRNAs from recent studies until October 2016 are reviewed and multiple studies that have confirmed CRC-associated IncRNAs are summarized. This review may be helpful in understanding the overall relationships between the IncRNAs involved in CRC.

\section{INTRODUCTION}

RNAs that do not encode proteins are called noncoding RNAs (ncRNA). Those with a length of more than 200 nucleotides are referred to as long non-coding RNAs (lncRNAs) [1]. LncRNAs play important roles in biological processes through interfering with mRNA activity, directly combining with proteins to regulate their activity or alter their localization, influencing downstream gene expression by inhibiting RNA polymerase, and regulating gene expression as competing endogenous RNAs (ceRNAs) [2, 3].

Colorectal cancer (CRC) is the third most commonly diagnosed cancer in humans [4]. CRC is a malignant lesion of the colorectal mucosal epithelium caused by environmental, genetic and epigenetic factors
[5]. The genesis of CRC is a multi-stage and multi-gene process, but the mechanism is not yet fully understood. Numerous lncRNAs have been discovered to be involved in influencing gene expression levels via chromatin modification, transcription and posttranscriptional processing [6]. With the discovery of novel molecular and epigenetic mechanisms in CRC, lncRNAs have become a rising biotarget for diagnostic, prognostic, and therapeutic applications. For example, colon cancer associated transcript 2 (CCAT2) underlies metastatic progression and chromosomal instability in colon cancer via the up-regulation of v-myc avian myelocytomatosis viral oncogene homolog (MYC), miR-17-5p, and miR-20a resulting in an enhancement in Wingless and Int1 (WNT) signaling activity [7]. Cancer susceptibility candidate 2 (CASC2) can act as an "miRNA sponges" and ceRNA by sponging miR-18a to upregulate protein inhibitor of 
activated signal transducer and activator of transcription 3 (PIAS3) and then consequentially inhibit of CRC cell proliferation and tumor growth by extending the $\mathrm{G} 0$ / G1-S phase transition [8]. Moreover, Long intergenic non-coding RNA 152 (Linc00152) as a ceRNA can confer oxaliplatin resistance via the Linc00152/miR-193a$3 \mathrm{p} /$ erb-b2 receptor tyrosine kinase 4 (ERBB4)/ serine/ threonine kinase 1 (AKT) signaling axis and acts as a prognostic indicator in colon cancer patients [9].

Although previous reviews have summarized the CRC-associated lncRNAs, a comprehensive and in-depth analysis of their mechanisms in the invasion, metastasis, early diagnosis, and prognosis of CRC has not yet been reported [10-12]. Herein, the latest papers concerning the 71 CRC-associated lncRNAs reported up to October 2016 are reviewed and multiple studies that have confirmed CRC-associated lncRNAs are summarized. This review may be helpful in understanding the overall relationships between the lncRNAs involved in CRC.

\section{LNCRNAS INVOLVED IN THE INVASION, METASTASIS, EARLY DIAGNOSIS, AND PROGNOSIS OF CRC}

\section{HOTAIR}

HOX transcript antisense RNA (HOTAIR) is the first lncRNA found to demonstrate a trans-transcriptional regulation function and it is located on chromosome 12q13.13. Previous studies have shown that HOTAIR plays an important role in many tumors including prostate cancer, gastric cancer, cervical cancer, and breast cancer [13-16]. HOTAIR interacts with the polycomb repressive complex 2 (PRC2; SUZ12, EZH2, and H3K27me3) and high HOTAIR expression is correlated with the presence of liver metastasis and poor prognosis in CRC patients [17]. Decreasing HOTAIR expression has been shown to inhibit the growth of human CRC stem cells [18]. HOTAIR has potential as a prognostic factor, as it is not only highly expressed in the primary tumors of CRC patients, but is also found in the peripheral blood [19]. HOTAIR can increase the expression of E-cadherin and decrease the expression of vimentin and matrix metallopeptidase 9 to function as a pleiotropic modulator participating in epithelial-mesenchymal transition (EMT), which is involved in CRC invasion, lymph node and organ metastasis, differentiation, vascular invasion and tumor staging [20].

\section{CCAT}

Colon cancer associated transcript 1 (CCAT1) is a recently discovered lncRNA of 2628 nucleotides in length. It is located on chromosome $8 \mathrm{q} 24.21,515 \mathrm{~kb}$ upstream of the MYC oncogene, in a region termed a "super enhancer" [21]. Previous research has shown that CCAT1 is involved in esophageal squamous cell carcinoma, glioma, colorectal carcinoma, and gastric cancer [22, 23]. Recent studies have demonstrated that the level of CCAT1 is significantly higher in the plasma of CRC patients compared with that of healthy controls [24, 25]. Increased plasma HOTAIR and CCAT1 together could be used as a predictive biomarker for CRC [25]. CCAT1 overexpression was associated with CRC proliferation and invasiveness, clinical stage, lymph node metastasis and survival time of CRC [26-28]. The bromodomain and extraterminal (BET) protein bromodomain containing 4 (BRD4) is critical for colon cancer proliferation, and decreasing levels of BRD4 influence differentiation effects during BET inhibition. Therefore, CCAT1 acts as an enhancer-templated RNA, which predicts BET sensitivity in CRC [29].

CCAT2, a novel lncRNA mapping to $8 \mathrm{q} 24$, is highly overexpressed in colon cancer and underlies metastatic progression and chromosomal instability in colon cancer [7]. Moreover, previous studies have found that CCAT2 is related with many tumor types such as glioma, gastric cancer, bladder cancer, and small cell lung cancer [3033]. MYC, miR-17-5p, and miR-20a are up-regulated by CCAT2 through transcription factor 7 like 2 (TCF7L2)mediated transcriptional regulation and the interaction between CCAT2 and TCF7L2 results in an enhancement in WNT signaling activity, which promotes tumor growth and metastasis in CRC [7].

\section{MALAT-1}

Metastasis associated lung adenocarcinoma transcript 1 (MALAT-1), also called nuclear enrichment autosomal transcript 2, is located on chromosome 11q13.1, has a total length of $8.7 \mathrm{~kb}$ and is involved in many types of cancer including pancreatic cancer, liver cancer, gastrointestinal cancer, breast cancer, and lung cancer [34-36]. MALAT-1 is highly expressed in CRC and it can promote the phosphorylation of serine and arginine rich splicing factor 1 (SRSF1), catalyzed by SRSF protein kinase 1-to increase the expression of A-kinase anchoring protein 9, and therefore promotes cell proliferation, invasion and metastasis in CRC $[37,38]$. High expression of MALAT-1 has been identified as a biomarker for poor prognosis in CRC [39]. The 3 'end of MALAT-1 is an important position in terms of invasion and metastasis in CRC [40]. MALAT1 interacts with Chemokine (C-C Motif) Ligand 5 in tumor-associated dendritic cells to mediate the progression of CRC [41].

\section{H19}

H19 is located on human chromosome 11p15.5 and is a $2.3 \mathrm{~kb} \operatorname{lncRNA}$, which constitutes a pair of 
imprinted genes together with the insulin-like growth factor-II gene (IGF2) [42]. Loss of imprinting of IGF2 in CRC is linked to hypomethylation of H19 and IGF2 [42]. H19 expression has been shown to be involved in solid tumors in a variety of cancers including lung cancer, breast cancer, and gastric cancer [43]. H19 recruits eukaryotic translation initiation factor 4A3 (eIF4A3) to promote CRC proliferation. Moreover, high expression of H19 is associated with tumor differentiation and tumor node metastasis (TNM) staging. H19 is an independent predictor of overall survival and disease-free survival in CRC patients [44]. Gene mutations such as rs2839698 in H19 have been linked with susceptibility to CRC and may function as a potential prognostic factor [45]. H19 was shown to modulate the expression of multiple genes involved in EMT by acting as a ceRNA for miR-138 and miR-200a to influence the migration of CRC [46]. H19 and its product miR-675 are highly expressed in CRC; high levels of miR-675 have been shown to reduce the expression of tumor suppressor retinoblastoma protein (RB) through recognizing and binding the 3 ' end of its UTR [47].

\section{IncRNA-p21}

lncRNA-p21 is regulated by p53 to reduce cell viability and its expression is lower in CRC [48]. Moreover, lncRNA-p21 levels in patients with stage III CRC are significantly higher than in those with stage I CRC [49]. IncRNA-p21 reduces cancer cell survival and self-renewal capacity and promotes cancer cell glycolysis via inhibiting the $\beta$-catenin signal to inhibit CRC cells with stem cell-like features from developing into mature cancer cells [50]. IncRNA-p21 is also involved in nonsmall cell lung cancer, gastric cancer, and hepatocellular carcinoma $[51,52]$.

\section{GAS5}

RNA-growth arrest-specific transcript 5 (GAS5) is located on the chromosome 1q25.1 and its length is 630 nucleotides. GAS5 has been found at different levels of expression in many types of cancer such as non-small cell lung cancer, breast cancer, and gastric cancer $[44,53$, 54]. A lower expression of GAS5 is associated with large tumor size, low histological grade and advanced TNM stage and GAS5 expression is an independent predictor for overall survival in CRC patients [55]. The latest literature shows that GAS5 rs 145204276 mutation is significantly associated with the susceptibility and progression in CRC, which implies that it contributes to lymphatic metastasis [56]. High expression levels of GAS5 are significantly associated with the future occurrence of liver metastases and poor prognosis in early stage CRC patients [57]. GAS5 is under the control of p53 and it plays an important role in mediating the p53 response to DNA damage [58].

\section{ANRIL}

Antisense non-coding RNA in the INK4 locus (ANRIL) is a natural antisense noncoding RNA and it transcribed from the antisense cluster of the INK4b-ARFINK4a gene[59]. It is located at Chr9p21.3 and has a 126.3 $\mathrm{kb}$ length [60]. ANRIL has been shown to be a prognostic indicator of nasopharyngeal carcinoma, non-small-cell lung cancer, and epithelial ovarian cancer [37,61]. ANRIL is upregulated in CRC tissues and is associated with survival rate, cell migration and invasion in CRC patients $[62,63]$. In CRC cells, ANRIL positively regulates the proliferation in two- and three-dimensional culture in a p15/p16-pRB pathway-independent manner [60].

\section{UCA1}

Urothelial carcinoma associated antigen 1 (UCA1) is a bladder cancer-specific lncRNA, with a total length of $1439 \mathrm{bp}$ and is located in the 19p13.12. It may produce an oncogenic effect related to glucose metabolism [64]. UCA1 is a common molecular marker for lymph node metastasis and prognosis in various cancers including breast cancer, esophageal cancer, and pancreatic cancer [65]. UCA1 is highly expressed in CRC and is involved in tumor cell proliferation, apoptosis and cell cycle progression of tumor and the prognosis of CRC patients $[66,67]$. Moreover, a meta-analysis has shown that UCA1 levels are negatively associated with the overall survival time of CRC patients [68]. Therefore, UCA1 has been identified as a predictive biomarker for the prognosis and survival of CRC patients.

\section{AFAP1-AS1}

Actin filament associated protein 1 antisense RNA 1 (AFAP1-AS1) is an antisense RNA gene encoding AFAP1, first identified in esophaguseal and Barrett tumor development, that may function as a potential biomarker to predict the clinical outcome of cancer patients including those with pancreatic ductal adenocarcinoma, esophageal squamous cell carcinoma, and gallbladder cancer [69, 70]. As a carcinogenic lncRNA, it is highly expressed in $\mathrm{CRC}$ and is involved in cell proliferation, colony formation, migration and invasion and it is closely related to tumor size, TNM stage and distant metastasis $[71,72]$. Knockdown of AFAP1-AS1 inhibits tumor growth and metastasis via the EMT pathway, indicating its potential to serve as an independent prognostic factor for patients with CRC [69, 71, 73].

\section{TUG1}

Taurine up-regulated gene 1 (TUG1) is located at the $22 \mathrm{q} 12.2$ and its transcript as a cancer progression 
related IncRNA, has been found to be involved in the oncogenesis of some tumors. TUG1 promotes cancer metastasis in cancers such as breast cancer, bladder cancer, hepatocellular carcinoma and osteosarcoma [74]. TUG1 regulates the expression of growth-related genes, activates the expression of EMT-associated genes and plays important roles in signal transduction, cell morphology, migration, proliferation and apoptosis in CRC [75]. Inhibition of TUG1 expression blocked the cell migration ability of colon cancer cells [76]. TUG1 is highly expressed in CRC and it indicates a poor prognosis for $\mathrm{CRC}$ and promotes metastasis [62].

\section{HOTTIP}

HOXA transcript at the distal tip (HOTTIP) has been recently discovered and is located at the 5 'end of HOX clusters. HOTTIP is a novel predictor of lymph node metastasis and survival in non-small cell lung cancer, gastric cancer and pancreatic cancer [77]. HOTTIP is highly expressed in CRC and promotes the growth of CRC partially via silencing of p21 expression [78]. Overexpression of HOTTIP is thought to be an independent poor prognostic factor for CRC patients [79].

\section{NEAT1}

Nuclear-enriched abundant transcript 1 (NEAT1) is a recently identified nuclear-restricted lncRNA, which has two isoforms including $3.7 \mathrm{~kb}$ NEAT1_1 and $23 \mathrm{~kb}$ NEAT1_2 [80]. NEAT1 has been reported to be involved in ovarian cancer, gastric cancer and breast cancer [81]. NEAT1 is a possible biomarker for diagnostic purposes, tumor recurrence and prognosis in CRC. The high expression of NEAT1 in the tissue and whole blood of CRC patients is associated with tumor differentiation, invasion, metastasis and TNM staging [82].

\section{BANCR}

BRAF-activated lncRNA (BANCR) was originally identified in melanoma cells with 693 bp in length, is located before the repeating cycle of chromosome 9 , is crucial for melanoma cell migration and is closely related to the $B R A F$ gene V600E mutation [83]. Overexpression of BANCR has been found in many types of cancer such as bladder cancer, esophageal squamous cell carcinoma, and hepatocellular carcinoma [84, 85]. BANCR is highly expressed in CRC and is related with lymph node metastasis and tumor staging [86]. BANCR induces EMT via a mitogen-activated protein kinase kinase/extracellular signal-regulated kinase-dependent mechanism and then enhances G0/G1 cell cycle arrest and apoptosis by regulating $\mathrm{p} 21[87,88]$. Shi $\mathrm{Y}$, et al. reported that
Ets-1 negatively regulates BANCR expression via the deacetylation of $\mathrm{H} 3$ histones within the BANCR promoter to influenced a fentanyl-induced mechanism, thereby inhibiting the invasion and migration of CRC cells [89].

\section{IncRNA-ATB}

lncRNA activated by transforming growth factor beta (TGF- $\beta$ ) (lncRNA-ATB) is involved in proliferation and metastasis in a variety of cancers including nonsmall cell lung cancer, glioma, and renal cell carcinoma and so on [90-92]. Its high expression in CRC patients is significantly associated with greater tumor size, depth of tumor invasion, lymphatic invasion, vascular invasion, and lymph node metastasis [93]. IncRNA-ATB as tumorigenesis suppresses E-cadherin expression and promotes EMT processes during tumorigenesis. Therefore, lncRNA-ATB provides a promising therapeutic biotarget against cancer progression in CRC patients [94].

\section{ZFAS1}

Zinc finger antisense 1(ZFAS1), a newly identified IncRNA, has been reported to be dysregulated in multiple human cancer types including $\mathrm{CRC}$, breast cancer, and gastric cancer [95-97]. The abundance of ZFAS1 expressed in $\mathrm{CRC}$ was found to correlate with lymphatic invasion, TNM stage, tumor invasion and metastasis. Patients who had shorter relapse-free survival and overall survival showed an increased expression of ZFAS1, and Cox multivariate analyses imply that ZFAS1 is an independent prognostic factor in CRC patients [98]. ZFAS1 may function as an oncogene in CRC via destabilization of p53 and through interaction with the CDK1/cyclin B1 complex leading to disease progression and apoptosis [95].

\section{SPRY4-IT1}

SPRY4 intronic transcript 1 (SPRY4-IT1), transcribed from an intron of the SPRY4 gene, has been reported to be dysregulated in various cancers including esophageal squamous cell carcinoma, breast cancer, and gastric cancer[99-101]. It may be useful as an independent predictor for overall survival in CRC patients [99]. SPRY4-IT1 is highly expressed in CRC and promotes cell migration and invasion by modifying the EMT pathway [100].

\section{MEG3}

Maternally expressed gene 3 (MEG3) is located at $14 \mathrm{q} 32.2$ and is involved in cancer development and metastasis. It is an imprinted gene expressed from the maternal allele with a length of approximately $1.6 \mathrm{~kb}$ from 
Table 1: The CRC-associated IncRNAs.

\begin{tabular}{|c|c|c|c|c|}
\hline $\operatorname{lncRNA}$ & Effects & Expression & Mechanisms in CRC from direct evidence & PMID \\
\hline HOTAIR & $\begin{array}{l}\text { Prognostic } \quad \text { marker, } \\
\text { carcinogenesis }\end{array}$ & Overexpressed & $\begin{array}{l}\text { Modifies EMT pathway; is associated with PRC2 } \\
\text { function. }\end{array}$ & $\begin{array}{l}27069543 ; 24583926 ; \\
21862635 ; 27298568 ; \\
24840737\end{array}$ \\
\hline CCAT1 & $\begin{array}{l}\text { Carcinogenesis, } \\
\text { development, invasion and } \\
\text { metastasis }\end{array}$ & Decreased & Is transcribed from the superenhancer cMYC. & $\begin{array}{l}27134049 ; 26752646 ; \\
26064266 ; 25185650 ; \\
23594791\end{array}$ \\
\hline CCAT2 & Pathogenesis & Overexpressed & $\begin{array}{l}\text { Regulates MYC, miR-17-5p, and miR-20a; modifies } \\
\text { WNT signaling pathway. }\end{array}$ & $23796952 ; 27875818$ \\
\hline MALAT-1 & Proliferation and metastasis & Overexpressed & $\begin{array}{l}\text { Promotes the phosphorylation of SRSF1 to increase } \\
\text { AKAP-9; interacts with Chemokine (C-C Motif) Ligand } \\
5 .\end{array}$ & $\begin{array}{l}25031737 ; 25446987 ; \\
25025966 ; 24244343 ; \\
27596298 ; 21503572 ; \\
27313790 ; 26887056\end{array}$ \\
\hline H19 & Prognostic biomarker & Overexpressed & $\begin{array}{l}\text { Modifies EMT pathway; is a ceRNA for miR-138 and } \\
\text { miR-200a; can recruit eIF4A3; mediates methotrexate } \\
\text { resistance through activating the WNT/ } \beta \text {-catenin } \\
\text { pathway; regulates essential Rb-E2F and CDK8- } \beta \text {-catenin } \\
\text { signaling. }\end{array}$ & $\begin{array}{l}\text { 26989025; 26068968; } \\
\text { 19926638; 27596298; } \\
\text { 27919747; 27789274 }\end{array}$ \\
\hline LincRNA-p21 & \begin{tabular}{|l|} 
Prognostic biomarker, \\
radiotherapy resistance
\end{tabular} & Decreased & $\begin{array}{l}\text { Is regulated by p53; inhibits the } \beta \text {-catenin signaling } \\
\text { pathway. }\end{array}$ & $\begin{array}{l}24012455 ; 26497997 ; \\
24573322\end{array}$ \\
\hline GAS5 & Prognostic biomarker & Decreased & Is under control of p53. & $\begin{array}{l}25326054 ; 26634743 ; \\
24926850 ; 27863421\end{array}$ \\
\hline ANRIL & Proliferation and metastasis & Overexpressed & Modifies p15/p16-pRB pathway. & $27314206 ; 26708220$ \\
\hline UCA1 & $\begin{array}{l}\text { Oncogenes and prognostic } \\
\text { factors; drug resistance }\end{array}$ & Overexpressed & Is related to glucose metabolism; inhibits miR-204-5p. & $\begin{array}{l}26380024 ; 27046651 ; \\
26238511 ; 24977734\end{array}$ \\
\hline AFAP1-AS1 & Proliferation and metastasis & Overexpressed & Modifies EMT pathway. & $\begin{array}{l}27578191 ; 27261589 ; \\
27596298\end{array}$ \\
\hline TUG1 & Proliferation, migration & Overexpressed & Modifies EMT pathway. & $\begin{array}{l}26856330 ; 27421138 ; \\
27634385\end{array}$ \\
\hline HOTTIP & Progression & Overexpressed & Can silence the expression of $\mathrm{p} 21$. & $26617875 ; 26678886$ \\
\hline BANCR & Tumorigenesis & Decreased & $\begin{array}{l}\text { Modifies EMT pathway via a MEK/extracellular signal- } \\
\text { regulated kinase-dependent mechanism; decreases p21. }\end{array}$ & $25928067 ; 25013510$ \\
\hline LncRNA-ATB & Proliferation and metastasis & Overexpressed & Suppresses E-cadherin and promotes the EMT pathway. & $26487301 ; 25750289$ \\
\hline ZFAS1 & $\begin{array}{|ll|}\text { Prognostic } & \text { indicator, } \\
\text { metastasis } & \\
\end{array}$ & Overexpressed & $\begin{array}{l}\text { Destabilizes p53 and interacts with the CDK1/cyclin B1 } \\
\text { complex. }\end{array}$ & $\begin{array}{l}26506418 ; 27461820 ; \\
27461828\end{array}$ \\
\hline SPRY4-IT1 & \begin{tabular}{|l|} 
Prognostic indicator, \\
proliferation and metastasis
\end{tabular} & Overexpressed & Modifies the EMT pathway. & $27391336 ; 27621655$ \\
\hline CLMAT3 & $\begin{array}{|ll|}\begin{array}{l}\text { Prognostic } \\
\text { proliferation }\end{array} & \text { biomarker, } \\
\end{array}$ & Decreased & $\begin{array}{l}\text { Its knockdown enhances } \mathrm{Cdh} 1 \text { and results in p27 Kip } \\
\text { accumulation via increased Skp2 protein ubiquitination. }\end{array}$ & $26050227 ; 27391344$ \\
\hline PVT-1 & $\begin{array}{l}\text { Risk factor, proliferation and } \\
\text { invasion }\end{array}$ & Overexpressed & Activates TGF- $\beta$ signaling pathway and apoptotic signals. & $27596298 ; 24196785$ \\
\hline MEG3 & $\begin{array}{l}\text { Diagnostic and prognostic } \\
\text { target }\end{array}$ & Decreased & Mediates TP53 signaling. & $\begin{array}{l}25636452 ; 27391432 ; \\
26934323\end{array}$ \\
\hline NEAT1 & Invasion and proliferation & Overexpressed & $\begin{array}{l}\text { Plays oncogenic role in colorectal cancer differentiation, } \\
\text { invasion and metastasis. }\end{array}$ & $26314847 ; 26552600$ \\
\hline $\mathrm{CASC} 2$ & Pathogenesis & Decreased & $\begin{array}{l}\text { Upregulates PIAS3 by functioning as a ceRNA for miR- } \\
18 \mathrm{a} \text {. }\end{array}$ & 27198161 \\
\hline Loc 554202 & Tumorigenesis & Decreased & Activation of specific caspase cleavage cascades. & $26362196 ; 27831651$ \\
\hline FER1L4 & $\begin{array}{l}\text { Cell proliferation, migration } \\
\text { and invasion }\end{array}$ & Decreased & $\begin{array}{l}\text { Through suppressing miR-106a-5p and depletion of } \\
\text { FER1L4, alone or combined with overexpression of miR- } \\
\text { 106a-5p. }\end{array}$ & 26224446 \\
\hline FEZF1-AS1 & \begin{tabular}{|l|l|}
$\begin{array}{l}\text { Tumorigenesis } \\
\text { progression }\end{array}$ & and \\
\end{tabular} & Overexpressed & $\begin{array}{l}\text { Interacts with hnRNP-K and activates the WNT/ } \beta \text {-catenin } \\
\text { pathway. }\end{array}$ & 26848625 \\
\hline CASC11 & Proliferation and metastasis & Overexpressed & $\begin{array}{l}\text { Targets hnRNP-K to activate } \mathrm{WNT} / \beta \text {-catenin signaling; } \\
\text { c-Myc directly binds to the promoter regions of CASC11 } \\
\text { and increases promoter histone }\end{array}$ & 27012187 \\
\hline SnaR & 5-FU-resistance & - & SnaR loss decreases sensitivity to 5-FU. & 25078450 \\
\hline SLC25A25-AS1 & $\begin{array}{l}\text { Proliferation, } \\
\text { chemoresistance }\end{array}$ & Decreased & $\begin{array}{l}\text { Promotes EMT process associated with Erk and p38 } \\
\text { signaling pathway activation. }\end{array}$ & 27553025 \\
\hline ZNF582-AS1 & Diagnostic biomarker & Methylation & Methylation of ZNF582-AS1. & 27215978 \\
\hline TINCR & Proliferation and metastasis & Decreased & $\begin{array}{l}\text { Loss of TINCR promotes hydrolysis of EpCAM and then } \\
\text { release of EpICD, subsequently, activates the WNT/ } \beta \text { - } \\
\text { catenin pathway. }\end{array}$ & 27009809 \\
\hline UPAT & Tumorigenesis & Overexpressed & $\begin{array}{l}\text { Interacts with and stabilizes the epigenetic factor UHRF1 } \\
\text { by interfering with its } \beta \text {-transducin repeat-containing } \\
\text { protein (TrCP)-mediated ubiquiti }\end{array}$ & 26768845 \\
\hline
\end{tabular}




\begin{tabular}{|c|c|c|c|c|}
\hline HULC & Prognostic indicator & Overexpressed & $\begin{array}{l}\text { Interacts with EZH2 to repress underlying target NKD2 } \\
\text { transcription. }\end{array}$ & 27496341 \\
\hline DACOR1 & Tumorigenesis & Overexpressed & $\begin{array}{l}\text { Induction of DACOR1 leads to the activation of tumor- } \\
\text { suppressor pathways and attenuation of cancer-associated } \\
\text { metabolic pathways. }\end{array}$ & 26307088 \\
\hline CCAL & $\begin{array}{l}\text { Progression and } \\
\text { chemotherapy resistance }\end{array}$ & Overexpressed & $\begin{array}{l}\text { Induces multidrug resistance (MDR) through activating } \\
\text { WNT/ } \beta \text {-catenin signaling by suppressing AP- } 2 \alpha \text { and } \\
\text { further upregulating MDR1/P-gp ex }\end{array}$ & 25994219 \\
\hline cir-ITCH & Tumorigenesis & Decreased & $\begin{array}{l}\text { Increases the level of ITCH, which is involved in the } \\
\text { inhibition of the WNT/ } \beta \text {-catenin pathway. }\end{array}$ & 26110611 \\
\hline ucoo $2 \mathrm{kmd} .1$ & Proliferation & Overexpressed & Regulates CD44 as a molecular decoy for miR211-3p. & 26974151 \\
\hline CTD903 & Prognostic indicator & Overexpressed & $\begin{array}{l}\text { Downregulates CTD903 enhanced WNT/ } \beta \text {-catenin } \\
\text { activation and increases transcription factor (Twist and } \\
\text { Snail) expression. }\end{array}$ & 27035092 \\
\hline LINC01133 & Prognostic biomarker & Decreased & $\begin{array}{l}\text { Is downregulated by TGF- } \beta \text {, which could inhibit EMT } \\
\text { and metastasis; inhibits EMT and metastasis by directly } \\
\text { binding to SRSF6. }\end{array}$ & 27443606 \\
\hline Lnc34a & Proliferation & Overexpressed & $\begin{array}{l}\text { Directly targets miR-34a; recruits Dnmt3a via PHB2 } \\
\text { and HDAC1 to methylate and deacetylate the miR-34a } \\
\text { promoter simultaneously. }\end{array}$ & 27077950 \\
\hline Sox2ot & Proliferation and metastasis & Overexpressed & $\begin{array}{l}\text { Cyclin B1 and Cdc } 25 \mathrm{C} \text { are downregulated by knockdown } \\
\text { of Sox2ot; decreases N-cadherin, increases E-cadherin. }\end{array}$ & 27353770 \\
\hline CRNDE-h & Prognostic indicator & Overexpressed & Is correlated with IRX5 mRNA expression. & $27042112 ; 27888803$ \\
\hline ENST00000430471 & Proliferation and invasion & Decreased & Cis-regulation and trans-regulation of co-expressed gene. & 27217770 \\
\hline HIF2PUT & Migration, invasion & Overexpressed & Is a regulator of HIF- $2 \alpha$. & 26648739 \\
\hline AK027294 & Proliferation and metastasis & Overexpressed & $\begin{array}{l}\text { Is associated with the regulation of caspase-3, caspase-8, } \\
\text { Bcl-2, MMP12, MMP9, and TWIST. }\end{array}$ & 26820130 \\
\hline Linc00152 & $\begin{array}{l}\text { Prognostic indicator, drug } \\
\text { resistance }\end{array}$ & Overexpressed & $\begin{array}{l}\text { Is ceRNA to modulate miR-193a-3p, and then ERBB4; } \\
\text { contributes to L-OHP resistance at least partly through } \\
\text { activating the AKT pathway. }\end{array}$ & 27633443 \\
\hline CTNNAP1 & Diagnostic biomarker & Decreased & $\begin{array}{l}\text { ceRNA cross-talk between pseudogene CTNNAP1 and its } \\
\text { cognate gene CTNNA1. }\end{array}$ & 27487124 \\
\hline PANDAR & Prognostic indicator & Overexpressed & $\begin{array}{l}\text { Modulates the EMT pathway through inhibiting } \\
\text { N-cadherin, vimentin, } \beta \text {-catenin, Snail and Twist } \\
\text { expression and increasing E-cadherin. }\end{array}$ & 27629879 \\
\hline GAPLINC & Proliferation and metastasis & Overexpressed & Binds to PSF/NONO and partly stimulates SNAI2. & 27259250 \\
\hline SNHG20 & $\begin{array}{l}\text { Proliferation, invasion and } \\
\text { migration }\end{array}$ & Overexpressed & Modulates a series of cell cycle-associated genes. & 27543107 \\
\hline $91 \mathrm{H}$ & Prognostic indicator & Overexpressed & Unclear & 25058480 \\
\hline ADAMTS9-AS2 & Prognostic indicator & Decreased & Unclear & 27596298 \\
\hline BCAR4/HOXA-AS2 & Prognostic indicator & Overexpressed & Unclear & 27596298 \\
\hline AK123657/BX64820 & Prognostic marker & Decreased & Unclear & 24809982 \\
\hline ENST00000465846 & Lymph node metastasis & Decreased & Unclear & 25009386 \\
\hline AK307796/ENST00 & Lymph node metastasis & Overexpressed & Unclear & 25009386 \\
\hline CAHM(LOC100526) & Tumorigenesis & Decreased & Unclear & 24799664 \\
\hline DANCR & Prognostic factor & Overexpressed & Unclear & 26617879 \\
\hline DQ786243 & Proliferation and metastasis & Overexpressed & Unclear & 26934980 \\
\hline FTX & Prognostic biomarker & Overexpressed & Unclear & 26629053 \\
\hline GHET1 & Proliferation and metastasis & Overexpressed & Unclear & 27131316 \\
\hline HOTAIRM1 & Prognostic biomarker & Decreased & Unclear & 27307307 \\
\hline LINC01296 & Prognostic biomarker & Overexpressed & Unclear & 25894381 \\
\hline LOC100287225 & Pathogenesis & Decreased & Unclear & $27062707 ; 26429648$ \\
\hline LOC285194 & Prognostic indicator & Decreased & Unclear & 23680400 \\
\hline ncRAN & Prognostic indicator & Decreased & Unclear & 24519959 \\
\hline ncRuPAR & Proliferation and metastasis & Decreased & Unclear & 25119598 \\
\hline NR_029373/NR_034 & Prognostic indicator & Decreased & Unclear & 27591862 \\
\hline PCAT-1 & Prognostic indicator & Overexpressed & Unclear & 23640607 \\
\hline PRNCR1 & Proliferation & Overexpressed & Unclear & $26530130 ; 24330491$ \\
\hline
\end{tabular}




\begin{tabular}{|l|l|l|l|l|}
\hline RP1-13P20.6 & Biomarker & Decreased & Unclear & 27596299 \\
\hline RP11-462C24.1 & Prognostic marker & Decreased & Unclear & $24954858 ; 27683121$ \\
\hline XLOC_006844/LOC & Tumorigenesis & Overexpressed & Unclear & 26328256 \\
\hline
\end{tabular}

Abbreviations: CRC, colorectal cancer; lncRNAs, long non-coding RNAs; ceRNA, competing endogenous RNAs; HOTAIR, HOX transcript antisense RNA; EMT, epithelial-mesenchymal transition; MMP-9, matrix metallopeptidase 9; MALAT-1, metastasis associated lung adenocarcinoma transcript 1; HOTAIR, human homeobox transcript antisense RNA; PRC2, polycomb repressive complex 2; CCAT1, colorectal cancer associated transcript 1; CCAT2, colorectal cancer associated transcript 2; BET, bromodomain and extraterminal; GAS5, RNA-growth arrest-specific transcript 5; snoRNAs, small nucleolar RNAs; siRNAs, small interfering RNAs. IGF2, Insulin-like growth factor-II gene; eIF4A3, eukaryotic translation initiation factor 4A3; NEAT2, nuclear enrichment autosomal transcript 2; AKAP-9, A-kinase anchoring protein 9; SRSF1, serine and arginine rich splicing factor 1; SRPK1, SRSF protein kinase 1; TNM, tumor node metastasis; RB, Retinoblastoma protein; ANRIL, Antisense non-coding RNA in the INK4 locus; UCA1, Urothelial carcinoma associated antigen 1; AFAP1-AS1, Actin filament associated protein 1 antisense RNA 1; TUG1, Taurine up-regulated gene 1; HOTTIP, HOXA transcript at the distal tip; NEAT1, Nuclear-enriched abundant transcript 1; BANCR, BRAF-activated lncRNA; lncRNA-ATB, Long non-coding RNA-activated by TGF- $\beta$; ZFAS1, Zinc finger antisense 1; SPRY4-IT1, SPRY4 intronic transcript 1; MEG3, Maternally expressed gene 3; PHD, Ubiquitin-like plant homeodomain; SNHG20, small nucleolar RNA host gene 20; PRNCR1, prostate cancer non-coding RNA 1; PCAT-1, Prostate cancer-associated ncRNA transcripts 1; 5-FU, 5-fluorouracil; CCAL, Colorectal cancer-associated lncRNA; Linc00152, Long intergenic non-coding RNA 152; MDR, multidrug resistance.

DLK1-MEG3 [102]. MEG3 is abnormally expressed in various human cancers, such as hepatocellular carcinoma, bladder cancer, glioma, gastric cancer and CRC [102-105]. Decreasing MEG3 levels could inhibit cell proliferation and predicts a poor prognosis in CRC patients [106]. Lower expression of MEG3 is significantly correlated with low histological grade, deep tumor invasion, and advanced TNM stage [106]. Moreover, the MEG3 rs7158663 AA genotype, not the GA genotype, significantly increases the risk of CRC [107].

\section{Other IncRNAs involved in CRC}

The important roles of the above-mentioned lncRNAs in the invasion, metastasis, early diagnosis, and prognosis of $\mathrm{CRC}$, have been confirmed through multiple studies. However, there are some other new lncRNAs with involvement in CRC, which have emerged in recent studies. ZNF582-AS1 was found to act as a novel tumor-suppressive lncRNA in CRC. Methylation of ZNF582-AS1 is associated with poor survival of CRC patients [108]. Ubiquitin-like plant homeodomain and really interesting new gene finger domain-containing protein 1 (UHRF1) protein associated transcript interacts with and stabilizes the epigenetic factor UHRF1 by interfering with its $\beta$-transducin repeat-containing protein-mediated ubiquitination to play a critical role in the survival and tumorigenicity of CRC [109]. Higher levels of lncRNA-uc002kmd.1 result in the regulation of CD44 as a molecular decoy for miR211-3p to enhance cell proliferation in CRC [110]. C-Myc represses the expression of tissue differentiation-inducing non-protein coding RNA (TINCR) through repressing sp1 transcriptive activity and loss of TINCR expression promotes proliferation and metastasis in CRC [111]. Enhanced expression of lncRNA small nucleolar RNAs (Sox2ot), small nucleolar RNA host gene 20 or prostate cancer non- coding RNA 1 promotes cell migration and invasion in CRC $[13,112,113]$. Lower expression of SLC25A25AS1 promotes proliferation, chemoresistance, and EMT in CRC [11]. RP11-462C24.1, RP1-13P20.6, Prostate cancerassociated ncRNA transcripts 1 , promoter of CDKN1A antisense DNA damage activated RNA (PANDAR), and non-coding RNA expressed in aggressive neuroblastoma were identified as the potential novel prognostic markers for CRC [114-118]. PVT-1 or LOC285194 expression levels are an independent risk factor for overall survival in CRC $[119,120]$. The expression of ncRuPAR is related to proliferation and metastasis in CRC patients [121]. Loc554202, LOC100287225 were identified to be tumorigenic in CRC $[122,123]$. Lnc34a is upregulated in $\mathrm{CRC}$, contributing to epigenetic miR-34a silencing and CRC proliferation [124]. Moreover, many other lncRNAs have been identified to contribute to invasion and metastasis, or aid in early diagnosis and prognosis in CRC via multiple mechanisms. All the CRC-related lncRNAs have been summarized in Table 1 .

\section{LncRNAs involved in chemoresistance and radioresistance in CRC}

Several types of genetic and epigenetic regulatory mechanisms have been identified as involved in the development of chemoresistance in cancer cells. Changes in the expression of lncRNAs are also responsible for resistance to chemotherapy and radiotherapy in cancer. The specific identities and roles of lncRNAs in treatment resistance remain to be more fully elucidated.

LncRNA-UCA1 decreased the 5-fluorouracil (5FU) chemosensitivity in CRC by attenuating apoptosis via inhibiting miR-204-5p [125]. The UCA1-miR-2045p-CREB1/BCL2/RAB22A regulatory network plays an important role in pathogenesis and chemoresistance in CRC patients [125]. Down-regulation of lncRNA 
Table 2: The CRC-associated IncRNAs with different pathways or interactions.

\begin{tabular}{|l|l|}
\hline Pathway or interactions & IncRNAs \\
\hline EMT pathway & $\begin{array}{l}\text { HOTAIR, H19, AFAP1-AS1, TUG1, BANCR, IncRNA-ATB, SPRY4-IT1, SLC25A25- } \\
\text { AS1, LINC0113, PANDAR, IncRNA-ATB, Sox2ot }\end{array}$ \\
\hline WNT pathway & CCAT2, CASC11, TINCR, CCAL, cir-ITCH, CTD903, H19 \\
\hline Interaction with miRNAs & CCAT2, H19, UCA1, CASC2, FER1L4, ucoo2kmd.1, Lnc34a, Linc00152, CTNNAP1 \\
\hline Silencing of p21 expression & HOTTIP, BANCR \\
\hline Involved with p53 & ZFAS1 \\
\hline TGF- $\beta$ signaling pathway & PVT-1, LINC01133 \\
\hline Erk and p38 pathway & SLC25A25-AS1 \\
\hline
\end{tabular}

Abbreviations: EMT, epithelial-mesenchymal transition; lncRNAs, long non-coding RNAs; HOTAIR, HOX transcript antisense RNA; AFAP1-AS1, Actin filament associated protein 1 antisense RNA 1; TUG1, Taurine up-regulated gene 1; BANCR, BRAF-activated lncRNA; SPRY4-IT1, SPRY4 intronic transcript 1; lncRNA-ATB, Long non-coding RNA-activated by TGF- $\beta$; CCAT1, colorectal cancer associated transcript 1; CCAT2, colorectal cancer associated transcript 2; CCAL, Colorectal cancer-associated lncRNA; Linc00152, Long intergenic non-coding RNA 152; ZFAS1, Zinc finger antisense 1

snaR decreased cell death after 5-FU treatment, which indicates that snaR loss increased the resistance against 5-FU in CRC [126]. Knockdown of SLC25A25-AS1 has been shown to enhance chemoresistance and promotes the EMT process associated with Erk and p38 signaling pathway activation in CRC [11]. Linc00152 acting as a ceRNA of miR-193a-3p increases the levels of ERBB4 contributing to oxaliplatin chemosensitivity in colon cancer [127]. Colorectal cancer-associated lncRNA (CCAL) was identified as modifying the response to adjuvant chemotherapy in $\mathrm{CRC}$ patients by inducing multidrug resistance (MDR) through activating WNT/ $\beta$ catenin signaling by suppressing AP-2 $\alpha$ and further upregulating MDR1/P-gp levels [128]. H19 has been shown to mediate methotrexate resistance via activating the WNT/ $\beta$-catenin pathway, and therefore H19 could be a promising therapeutic target for methotrexate-resistant CRC [129].

Radiotherapy is a standard preoperative treatment approach for local advanced cancer to reduce local recurrence [130]. The down-regulation of HOTAIR has been shown to improve the radiosensitivity of CRC cells [131] and lncRNA-p21 can enhance CRC radiosensitivity by targeting the $\mathrm{WNT} / \beta$-catenin signaling pathway [130].

\section{The mechanisms of CRC-associated IncRNAs}

Although numerous CRC-related lncRNAs have been identified, to date, little is known of their mechanisms of action. The known mechanisms have been summarized in Table 2. lncRNAs nearly affect the whole life cycle of genes, from transcription to RNA splicing, degradation and translation, and regulate gene expression via diverse mechanisms [11]. From healthy cells to tumor cells and metastases, and even in chemotherapy and radiotherapy resistance, lncRNAs are involved in every aspect of CRC. They can act not only as the major transcription factor but also as one of the co-regulatory factors; they are not only involved in EMT and WNT pathway but also can interact with miRNAs.

EMT is an important step in cancer development, which involves the cooperation of a variety of signaling pathways including the transformation growth factor- $\beta$, Sonic Hedgehog, and WNT pathways [132, 133]. As shown in Table 2, HOTAIR, H19, AFAP1-AS1, TUG1, BANCR, IncRNA-ATB, SPRY4-IT1, SLC25A25-AS1, LINC01133, PANDAR, lncRNA-ATB and Sox2ot wereare involved in the EMT pathway. These lncRNAs could increase the levels of E-cadherin, vimentin, ZEB1, ZEB2, and MMP9, all of which are core marker genes for mesenchymal cells.

Moreover, CCAT2 [7], H19 [129], CASC11 [134], TINCR [111], CCAL [128], cir-ITCH [82], and CTD903 [135] are involved in the WNT pathway, which also regulates gene expression changes during EMT[111]. WNT signaling can promote cancer progression-associated EMT processes via $\beta$-catenin-mediated increased gene expression at the invasive front of colorectal tumors [136].

The CRC-associated lncRNAs that interact with miRNAs are as follows and are shown in Figure 1: CCAT2 [7], H19 [46], UCA1 [125], CASC2 [8], FER1L4 [137], uc002kmd.1 [110], Lnc34a [138], Linc00152 [9], 
CTNNAP1 [139]. As ceRNAs and "miRNA sponges", lncRNAs can antagonize miRNA function by inhibiting their endogenous targets, thereby imposing an additional level of post-transcriptional regulation [114].

Other IncRNAs have different mechanisms to carry out their functions (Table 1, Table 2). For example, HOTTIP and BANCR potentially contribute to CRC cell growth partially through the silencing of $\mathrm{p} 21$ expression $[78,88]$.ZFAS1 may function as an oncogene in CRC via destabilization of p53 [95]. It is not surprising that the action of lncRNAs in CRC does not involve a single mechanism, but a variety of mechanisms co-exist. For example, $\mathrm{H} 19$ can function as a ceRNA for miR-138 and miR-200a to influence the migration of CRC cells and H19-derived miR-675 regulates the RB tumor suppressor in CRC $[46,47]$. However, H19 recruits eIF4A3 to promote CRC proliferation [44].

\section{CONCLUSIONS AND FUTURE PERSPECTIVES}

lncRNAs play important roles in invasion and metastasis, early diagnosis, prognosis, and chemoresistance and radioresistance in CRC. Large-scale genomic studies using chips to investigate the abnormal expression profiles of IncRNAs in tumors have been carried out and a variety of cancer-related IncRNAs have been reported. However, the molecular mechanisms of these dysregulated lncRNAs remain poorly characterized. Here, all the publications concerning the relationships between IncRNAs and CRC have been reviewed and summarized. As shown in Table 1, Table 2 and Figure 1 , there are more than $71 \mathrm{CRC}$-associated lncRNAs that have been found to date and clear mechanisms have been reported for some of these. However, the full mechanisms underlying all the CRC-associated lncRNAs are currently not understood. Therefore, further functional studies investigating how these related lncRNAs impact on all the processes in CRC in cells, animal models and human clinical trials are needed to advance this research.

Although recent advancements in technology have enabled the rapid development of research into CRCrelated lncRNAs, enormous challenges still exist. Firstly, the low levels of some lncRNAs in body fluid or tissues necessitate the use of advanced and reliable protocols of lncRNA amplification and enrichment. Secondly, finding

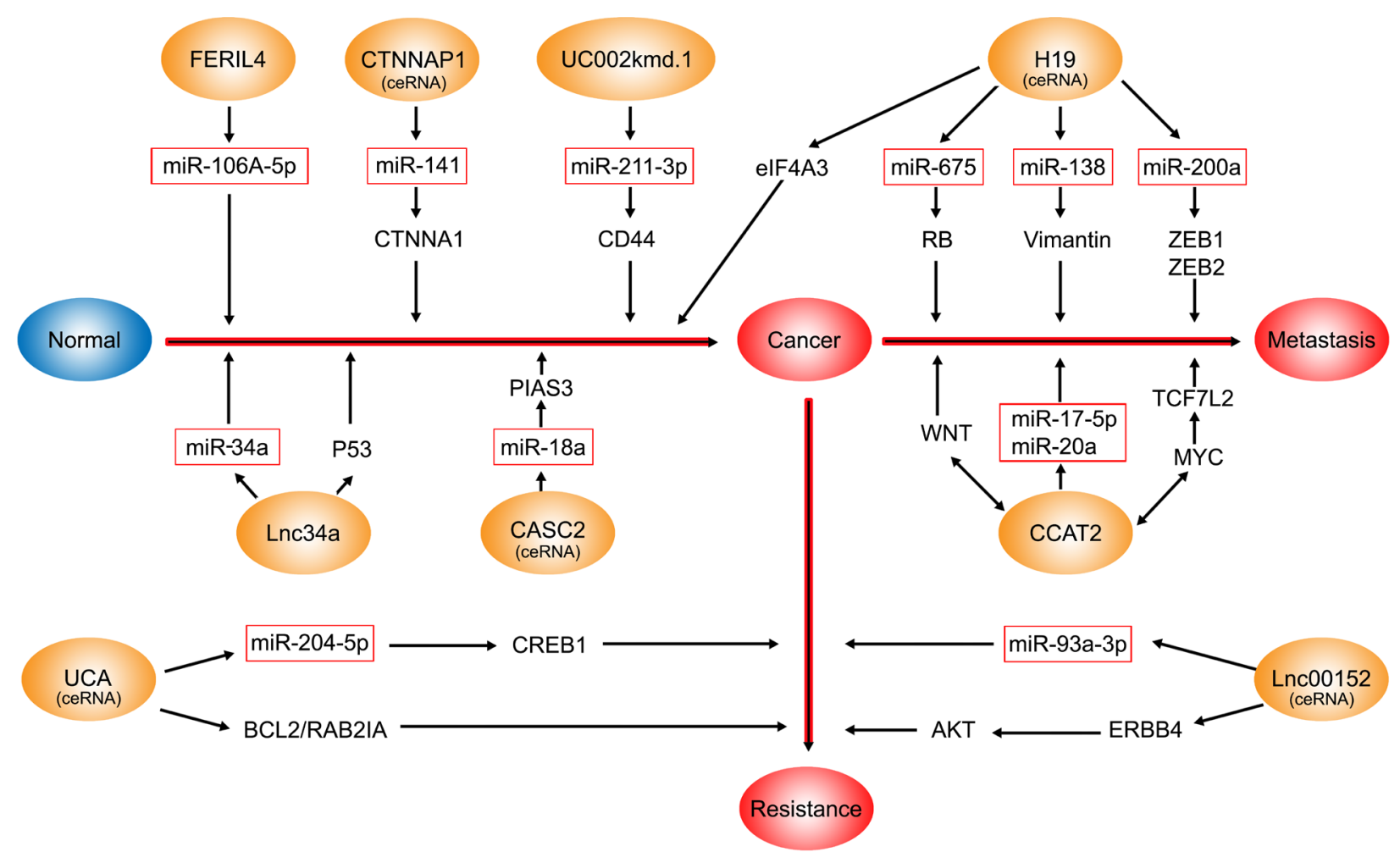

Figure 1: The CRC-associated IncRNAs which interact with miRNAs. The blue oval represents normal; the orange ovals represent lncRNAs involved in the interaction with miRNAs; the red rectangles represent miRNAs. FER1L4, CTNNAP1, CASC2, uc002kmd.1, and lnc34a interact with miRNAs to contribute to the pathogenesis of CRC. H19 and CCAT2 are involved in the metastasis and proliferation of CRC via multiple mechanisms including functioning as ceRNAs and through the WNT signaling pathway. Moreover, $\mathrm{H} 19$ also promotes tumor growth by recruiting and binding to eIF4A3. The UCA1-miR-204-5p-CREB1/BCL2/RAB22A regulatory network plays an important role in chemoresistance in CRC. Inc00152 acting as a ceRNA of miR-193a-3p increases the levels of ERBB4, contributing to oxaliplatin chemosensitivity in colon cancer. 
highly specific and sensitive biomarkers from the many CRC-associated lncRNAs is also a huge challenge because many lncRNAs are also involved in the development, invasion, metastasis, chemoresistance and radioresistance of other types of cancer. Moreover, determining the significance of specific lncRNAs in CRC and identifying the real protagonists is a challenge, considering the impact of confounding factors such as race, subject numbers, and TNM. However, despite such challenges, there is reason for optimism.

\section{Abbreviations}

CRC, colorectal cancer; lncRNAs, long non-coding RNAs; ceRNA, competing endogenous RNAs; EMT, epithelial-mesenchymal transition; MALAT-1, metastasis associated lung adenocarcinoma transcript 1; HOTAIR, human homeobox transcript antisense RNA; PRC2, polycomb repressive complex 2; CCAT1, colorectal cancer associated transcript 1; CCAT2, colorectal cancer associated transcript 2; BET, bromodomain and extraterminal; GAS5, RNA-growth arrest-specific transcript 5; snoRNAs, small nucleolar RNAs; siRNAs, small interfering RNAs; IGF2, Insulin-like growth factorII gene; eIF4A3, eukaryotic translation initiation factor 4A3; SRSF1, serine and arginine rich splicing factor 1; ncRAN, non-coding RNA expressed in aggressive neuroblastoma; TNM, tumor node metastasis; RB, Retinoblastoma protein; ANRIL, Antisense non-coding RNA in the INK4 locus; UCA1, Urothelial carcinoma associated antigen 1; AFAP1-AS1, Actin filament associated protein 1 antisense RNA 1; TUG1, Taurine up-regulated gene 1; HOTTIP, HOXA transcript at the distal tip; NEAT1, Nuclear-enriched abundant transcript 1; BANCR, BRAF-activated IncRNA; IncRNA-ATB, Long non-coding RNA-activated by TGF- $\beta$; ZFAS1, Zinc finger antisense 1; SPRY4-IT1, SPRY4 intronic transcript 1; MEG3, Maternally expressed gene 3; UHRF1, finger domain-containing protein 1; 5-FU, 5-fluorouracil; CCAL, Colorectal cancer-associated lncRNA; Linc00152, Long intergenic non-coding RNA 152; MDR, multidrug resistance

\section{ACKNOWLEDGMENTS}

We thank the supported grants of the National Scientific foundation of China (No. 81503166, 81603208) and the Youth Foundation of Xiangya Hospital in Central South University (2014Q08).

\section{CONFLICTS OF INTEREST}

The authors declare no conflicts of interest.

\section{FUNDING}

This work was supported by the National Scientific foundation of China (No. 81503166, 81603208) and the Youth Foundation of Xiangya Hospital in Central South University (2014Q08).

\section{REFERENCES}

1. Consortium EP. An integrated encyclopedia of DNA elements in the human genome. Nature. 2012; 489:57-74.

2. Wilusz JE, Sunwoo H and Spector DL. Long noncoding RNAs: functional surprises from the RNA world. Genes \& development. 2009; 23:1494-1504.

3. Tay Y, Rinn J and Pandolfi PP. The multilayered complexity of ceRNA crosstalk and competition. Nature. 2014; 505:344-352.

4. Jemal A, Bray F, Center MM, Ferlay J, Ward E and Forman D. Global cancer statistics. CA Cancer J Clin. 2011; 61:6990.

5. Haggar FA and Boushey RP. Colorectal cancer epidemiology: incidence, mortality, survival, and risk factors. Clinics in colon and rectal surgery. 2009; 22:191197.

6. Guttman M and Rinn JL. Modular regulatory principles of large non-coding RNAs. Nature. 2012; 482:339-346.

7. Ling H, Spizzo R, Atlasi Y, Nicoloso M, Shimizu M, Redis RS, Nishida N, Gafa R, Song J, Guo Z, Ivan C, Barbarotto E, De Vries I, et al. CCAT2, a novel noncoding RNA mapping to $8 \mathrm{q} 24$, underlies metastatic progression and chromosomal instability in colon cancer. Genome Res. $2013 ; 23: 1446-1461$.

8. Huang $\mathrm{G}, \mathrm{Wu} \mathrm{X}, \mathrm{Li} \mathrm{S}, \mathrm{Xu} \mathrm{X}, \mathrm{Zhu} \mathrm{H}$ and Chen $\mathrm{X}$. The long noncoding RNA CASC2 functions as a competing endogenous RNA by sponging miR-18a in colorectal cancer. Sci Rep. 2016; 6:26524.

9. Yue B, Cai D, Liu C, Fang C and Yan D. Linc00152 Functions as a Competing Endogenous RNA to Confer Oxaliplatin Resistance and Holds Prognostic Values in Colon Cancer. Mol Ther. 2016; 24:2064-2077.

10. Saus E, Brunet-Vega A, Iraola-Guzman S, Pegueroles C, Gabaldon T and Pericay C. Long Non-Coding RNAs As Potential Novel Prognostic Biomarkers in Colorectal Cancer. Front Genet. 2016; 7:54.

11. Xie X, Tang B, Xiao YF, Xie R, Li BS, Dong H, Zhou JY and Yang SM. Long non-coding RNAs in colorectal cancer. Oncotarget. 2016; 7:5226-5239. doi: 10.18632/ oncotarget.6446.

12. Ye LC, Zhu X, Qiu JJ, Xu J and Wei Y. Involvement of long non-coding RNA in colorectal cancer: From benchtop to bedside (Review). Oncology letters. 2015; 9:1039-1045.

13. Aiello A, Bacci L, Re A, Ripoli C, Pierconti F, Pinto F, Masetti R, Grassi C, Gaetano C, Bassi PF, Pontecorvi A, Nanni S and Farsetti A. MALAT1 and HOTAIR Long Non- 
Coding RNAs Play Opposite Role in Estrogen-Mediated Transcriptional Regulation in Prostate Cancer Cells. Sci Rep. 2016; 6:38414.

14. Yan J, Dang Y, Liu S, Zhang Y and Zhang G. LncRNA HOTAIR promotes cisplatin resistance in gastric cancer by targeting miR-126 to activate the PI3K/AKT/MRP1 genes. Tumour Biol. 2016.

15. Sun J, Chu H, Ji J, Huo G, Song Q and Zhang X. Long noncoding RNA HOTAIR modulates HLA-G expression by absorbing miR-148a in human cervical cancer. Int J Oncol. 2016; 49:943-952.

16. Milevskiy MJ, Al-Ejeh F, Saunus JM, Northwood KS, Bailey PJ, Betts JA, McCart Reed AE, Nephew KP, Stone A, Gee JM, Dowhan DH, Dray E, Shewan AM, et al. Long-range regulators of the lncRNA HOTAIR enhance its prognostic potential in breast cancer. Hum Mol Genet. 2016.

17. Kogo R, Shimamura T, Mimori K, Kawahara K, Imoto S, Sudo T, Tanaka F, Shibata K, Suzuki A, Komune S, Miyano S and Mori M. Long noncoding RNA HOTAIR regulates polycomb-dependent chromatin modification and is associated with poor prognosis in colorectal cancers. Cancer research. 2011; 71:6320-6326.

18. Dou J, Ni Y, He X, Wu D, Li M, Wu S, Zhang R, Guo $\mathrm{M}$ and Zhao F. Decreasing lncRNA HOTAIR expression inhibits human colorectal cancer stem cells. American journal of translational research. 2016; 8:98-108.

19. Svoboda M, Slyskova J, Schneiderova M, Makovicky P, Bielik L, Levy M, Lipska L, Hemmelova B, Kala Z, Protivankova M, Vycital O, Liska V, Schwarzova L, Vodickova L and Vodicka P. HOTAIR long non-coding RNA is a negative prognostic factor not only in primary tumors, but also in the blood of colorectal cancer patients. Carcinogenesis. 2014; 35:1510-1515.

20. Wu ZH, Wang XL, Tang HM, Jiang T, Chen J, Lu S, Qiu GQ, Peng ZH and Yan DW. Long non-coding RNA HOTAIR is a powerful predictor of metastasis and poor prognosis and is associated with epithelial-mesenchymal transition in colon cancer. Oncol Rep. 2014; 32:395-402.

21. Younger ST and Rinn JL. 'Lnc'-ing enhancers to MYC regulation. Cell research. 2014; 24:643-644.

22. Zhang E, Han L, Yin D, He X, Hong L, Si X, Qiu M, Xu T, De W, Xu L, Shu Y and Chen J. H3K27 acetylation activated-long non-coding RNA CCAT1 affects cell proliferation and migration by regulating SPRY4 and HOXB13 expression in esophageal squamous cell carcinoma. Nucleic Acids Res. 2016.

23. Guo X and Hua Y. CCAT1: an oncogenic long noncoding RNA in human cancers. J Cancer Res Clin Oncol. 2016.

24. Nissan A, Stojadinovic A, Mitrani-Rosenbaum S, Halle D, Grinbaum R, Roistacher M, Bochem A, Dayanc BE, Ritter G, Gomceli I, Bostanci EB, Akoglu M, Chen YT, Old LJ and Gure AO. Colon cancer associated transcript-1: a novel RNA expressed in malignant and pre-malignant human tissues. International journal of cancer. 2012; 130:15981606.

25. Zhao W, Song $M$, Zhang J, Kuerban $M$ and Wang $H$. Combined identification of long non-coding RNA CCAT1 and HOTAIR in serum as an effective screening for colorectal carcinoma. International journal of clinical and experimental pathology. 2015; 8:14131-14140.

26. He X, Tan X, Wang X, Jin H, Liu L, Ma L, Yu H and Fan Z. C-Myc-activated long noncoding RNA CCAT1 promotes colon cancer cell proliferation and invasion. Tumour Biol. 2014; 35:12181-12188.

27. Alaiyan B, Ilyayev N, Stojadinovic A, Izadjoo M, Roistacher M, Pavlov V, Tzivin V, Halle D, Pan H, Trink B, Gure AO and Nissan A. Differential expression of colon cancer associated transcript1 (CCAT1) along the colonic adenoma-carcinoma sequence. BMC cancer. 2013; 13:196.

28. Ye Z, Zhou M, Tian B, Wu B and Li J. Expression of lncRNA-CCAT1, E-cadherin and N-cadherin in colorectal cancer and its clinical significance. International journal of clinical and experimental medicine. 2015; 8:3707-3715.

29. McCleland ML, Mesh K, Lorenzana E, Chopra VS, Segal E, Watanabe C, Haley B, Mayba O, Yaylaoglu M, Gnad F and Firestein R. CCAT1 is an enhancer-templated RNA that predicts BET sensitivity in colorectal cancer. The Journal of clinical investigation. 2016; 126:639-652.

30. Zeng J, Du T, Song Y, Gao Y, Li F, Wu R, Chen Y, Li W, Zhou H, Yang Y and Pei Z. Knockdown of long noncoding RNA CCAT2 inhibits cellular proliferation, invasion, and EMT in glioma cells. Oncol Res. 2016.

31. Guo H, Hu G, Yang Q, Zhang P, Kuang W, Zhu X and $\mathrm{Wu}$ L. Knockdown of long non-coding RNA CCAT2 suppressed proliferation and migration of glioma cells. Oncotarget. 2016; 7:81806-81814. doi: 10.18632/ oncotarget.13242.

32. Chen S, Wu H, Lv N, Wang H, Wang Y, Tang Q, Shao H and Sun C. LncRNA CCAT2 predicts poor prognosis and regulates growth and metastasis in small cell lung cancer. Biomed Pharmacother. 2016; 82:583-588.

33. Li J, Zhuang C, Liu Y, Chen M, Zhou Q, Chen Z, He A, Zhao G, Guo Y, Wu H, Cai Z and Huang W. shRNA targeting long non-coding RNA CCAT2 controlled by tetracycline-inducible system inhibits progression of bladder cancer cells. Oncotarget. 2016; 7:28989-28997. doi: 10.18632/oncotarget.8259.

34. Han T, Jiao F, Hu H, Yuan C, Wang L, Jin ZL, Song WF and Wang LW. EZH2 promotes cell migration and invasion but not alters cell proliferation by suppressing E-cadherin, partly through association with MALAT-1 in pancreatic cancer. Oncotarget. 2016; 7:11194-11207. doi: 10.18632/ oncotarget. 7156 .

35. Tang R, Jiang M, Liang L, Xiong D, Dang Y and Chen G. Long Noncoding RNA MALAT-1 Can Predict Poor Prognosis: A Meta-Analysis. Med Sci Monit. 2016; 22:302309. 
36. Wang Y, Xue D, Li Y, Pan X, Zhang X, Kuang B, Zhou M, Li X, Xiong W, Li G, Zeng Z and Yang T. The Long Noncoding RNA MALAT-1 is A Novel Biomarker in Various Cancers: A Meta-analysis Based on the GEO Database and Literature. J Cancer. 2016; 7:991-1001.

37. Liu FT, Zhu PQ, Luo HL, Zhang Y, Hao TF, Xia GF, Zhu ZM and Qiu C. Long noncoding RNA ANRIL: a potential novel prognostic marker in cancer: a meta-analysis. Minerva Med. 2016; 107:77-83.

38. Yang MH, Hu ZY, Xu C, Xie LY, Wang XY, Chen SY and Li ZG. MALAT1 promotes colorectal cancer cell proliferation/migration/invasion via PRKA kinase anchor protein 9. Biochimica et biophysica acta. 2015; 1852:166174.

39. Zheng HT, Shi DB, Wang YW, Li XX, Xu Y, Tripathi P, Gu WL, Cai GX and Cai SJ. High expression of lncRNA MALAT1 suggests a biomarker of poor prognosis in colorectal cancer. International journal of clinical and experimental pathology. 2014; 7:3174-3181.

40. Xu C, Yang M, Tian J, Wang X and Li Z. MALAT-1: a long non-coding RNA and its important 3' end functional motif in colorectal cancer metastasis. Int J Oncol. 2011; 39:169-175.

41. Kan JY, Wu DC, Yu FJ, Wu CY, Ho YW, Chiu YJ, Jian SF, Hung JY, Wang JY and Kuo PL. Chemokine (C-C Motif) Ligand 5 is Involved in Tumor-Associated Dendritic CellMediated Colon Cancer Progression Through Non-Coding RNA MALAT-1. Journal of cellular physiology. 2015; 230:1883-1894.

42. Cui H, Onyango P, Brandenburg S, Wu Y, Hsieh CL and Feinberg AP. Loss of imprinting in colorectal cancer linked to hypomethylation of H19 and IGF2. Cancer research. 2002; 62:6442-6446.

43. Liu FT, Pan H, Xia GF, Qiu C and Zhu ZM. Prognostic and clinicopathological significance of long noncoding RNA H19 overexpression in human solid tumors: evidence from a meta-analysis. Oncotarget. 2016; 7:83177-83186. doi: 10.18632/oncotarget.13076.

44. Liu X, Jiao T, Wang Y, Su W, Tang Z and Han C. Long non-coding RNA GAS5 acts as a molecular sponge to regulate miR-23a in gastric cancer. Minerva Med. 2016.

45. Li S, Hua Y, Jin J, Wang H, Du M, Zhu L, Chu H, Zhang $\mathrm{Z}$ and Wang $\mathrm{M}$. Association of genetic variants in lncRNA H19 with risk of colorectal cancer in a Chinese population. Oncotarget. 2016; 7:25470-25477. doi: 10.18632/ oncotarget.8330.

46. Liang WC, Fu WM, Wong CW, Wang Y, Wang WM, Hu GX, Zhang L, Xiao LJ, Wan DC, Zhang JF and Waye MM. The lncRNA H19 promotes epithelial to mesenchymal transition by functioning as miRNA sponges in colorectal cancer. Oncotarget. 2015; 6:22513-22525. doi: 10.18632/ oncotarget. 4154.

47. Tsang WP, Ng EK, Ng SS, Jin H, Yu J, Sung JJ and Kwok TT. Oncofetal H19-derived miR-675 regulates tumor suppressor RB in human colorectal cancer. Carcinogenesis. 2010; 31:350-358.

48. Huarte M, Guttman M, Feldser D, Garber M, Koziol MJ, Kenzelmann-Broz D, Khalil AM, Zuk O, Amit I, Rabani M, Attardi LD, Regev A, Lander ES, Jacks T and Rinn JL. A large intergenic noncoding RNA induced by p53 mediates global gene repression in the p53 response. Cell. 2010; 142:409-419.

49. Zhai H, Fesler A, Schee K, Fodstad O, Flatmark K and $\mathrm{Ju}$ J. Clinical significance of long intergenic noncoding RNA-p21 in colorectal cancer. Clinical colorectal cancer. $2013 ; 12: 261-266$.

50. Guo XB, Hua Z, Li C, Peng LP, Wang JS, Wang B and Zhi QM. Biological significance of long non-coding RNA FTX expression in human colorectal cancer. International journal of clinical and experimental medicine. 2015; 8:1559115600 .

51. Yang N, Fu Y, Zhang H, Sima H, Zhu N and Yang G. LincRNA-p21 activates endoplasmic reticulum stress and inhibits hepatocellular carcinoma. Oncotarget. 2015; 6:28151-28163. doi: 10.18632/oncotarget.4661.

52. Tang SS, Zheng BY and Xiong XD. LincRNA-p21: Implications in Human Diseases. Int J Mol Sci. 2015; 16(8):18732-18740.

53. Liang W, Lv T, Shi X, Liu H, Zhu Q, Zeng J, Yang W, Yin $\mathrm{J}$ and Song Y. Circulating long noncoding RNA GAS5 is a novel biomarker for the diagnosis of nonsmall cell lung cancer. Medicine (Baltimore). 2016; 95:e4608.

54. Pickard MR and Williams GT. The hormone response element mimic sequence of GAS5 lncRNA is sufficient to induce apoptosis in breast cancer cells. Oncotarget. 2016; 7:10104-10116. doi: 10.18632/oncotarget.7173.

55. Yin D, He X, Zhang E, Kong R, De W and Zhang Z. Long noncoding RNA GAS5 affects cell proliferation and predicts a poor prognosis in patients with colorectal cancer. Medical oncology. 2014; 31:253.

56. Zheng Y, Song D, Xiao K, Yang C, Ding Y, Deng W and Tong S. LncRNA GAS5 contributes to lymphatic metastasis in colorectal cancer. Oncotarget. 2016; 7:83727-83734. doi: 10.18632/oncotarget.13384.

57. Kong H, Wu Y, Zhu M, Zhai C, Qian J, Gao X, Wang S, Hou Y, Lu S and Zhu H. Long non-coding RNAs: novel prognostic biomarkers for liver metastases in patients with early stage colorectal cancer. Oncotarget. 2016; 7:5042850436. doi: 10.18632/oncotarget.10416.

58. Krell J, Frampton AE, Mirnezami R, Harding V, De Giorgio A, Roca Alonso L, Cohen P, Ottaviani S, Colombo T, Jacob J, Pellegrino L, Buchanan G, Stebbing J and Castellano L. Growth arrest-specific transcript 5 associated snoRNA levels are related to p53 expression and DNA damage in colorectal cancer. PloS one. 2014; 9:e98561.

59. Li CH and Chen Y. Targeting long non-coding RNAs in cancers: progress and prospects. The international journal of biochemistry \& cell biology. 2013; 45:1895-1910. 
60. Naemura M, Tsunoda T, Inoue Y, Okamoto H, Shirasawa S and Kotake Y. ANRIL regulates the proliferation of human colorectal cancer cells in both two- and three-dimensional culture. Molecular and cellular biochemistry. 2016; 412:141-146.

61. Zou ZW, Ma C, Medoro L, Chen L, Wang B, Gupta R, Liu T, Yang XZ, Chen TT, Wang RZ, Zhang WJ and Li PD. LncRNA ANRIL is up-regulated in nasopharyngeal carcinoma and promotes the cancer progression via increasing proliferation, reprograming cell glucose metabolism and inducing side-population stem-like cancer cells. Oncotarget. 2016; 7:61741-61754. doi: 10.18632/ oncotarget.11437.

62. Sun Y, Zheng ZP, Li H, Zhang HQ and Ma FQ. ANRIL is associated with the survival rate of patients with colorectal cancer, and affects cell migration and invasion in vitro. Molecular medicine reports. 2016; 14:1714-1720.

63. Sun Z, Ou C, Ren W, Xie X, Li X and Li G. Downregulation of long non-coding RNA ANRIL suppresses lymphangiogenesis and lymphatic metastasis in colorectal cancer. Oncotarget. 2016; 7:47536-47555. doi: 10.18632/oncotarget.9868.

64. Li Z, Li X, Wu S, Xue M and Chen W. Long noncoding RNA UCA1 promotes glycolysis by upregulating hexokinase 2 through the mTOR-STAT3/microRNA143 pathway. Cancer science. 2014; 105:951-955.

65. He A, Hu R, Chen Z, Liao X, Li J, Wang D, Lv Z, Liu Y, Wang $\mathrm{F}$ and Mei H. Role of long noncoding RNA UCA1 as a common molecular marker for lymph node metastasis and prognosis in various cancers: a meta-analysis. Oncotarget. 2017; 8:1937-1943. doi: 10.18632/oncotarget. 12463.

66. Wang HM, Lu JH, Chen WY and Gu AQ. Upregulated lncRNA-UCA1 contributes to progression of lung cancer and is closely related to clinical diagnosis as a predictive biomarker in plasma. International journal of clinical and experimental medicine. 2015; 8:11824-11830.

67. Ni B, Yu X, Guo X, Fan X, Yang Z, Wu P, Yuan Z, Deng Y, Wang J, Chen D and Wang L. Increased urothelial cancer associated 1 is associated with tumor proliferation and metastasis and predicts poor prognosis in colorectal cancer. Int J Oncol. 2015; 47:1329-1338.

68. Hong HH, Hou LK, Pan X, Wu CY, Huang H, Li B and Nie W. Long non-coding RNA UCA1 is a predictive biomarker of cancer. Oncotarget. 2016; 7:44442-44447. doi: 10.18632/ oncotarget.10142.

69. Wang F, Ni H, Sun F, Li M and Chen L. Overexpression of lncRNA AFAP1-AS1 correlates with poor prognosis and promotes tumorigenesis in colorectal cancer. Biomed Pharmacother. 2016; 81:152-159.

70. Liu FT, Xue QZ, Zhu PQ, Luo HL, Zhang Y and Hao T. Long noncoding RNA AFAP1-AS1, a potential novel biomarker to predict the clinical outcome of cancer patients: a meta-analysis. Onco Targets Ther. 2016; 9:4247-4254.

71. Han X, Wang L, Ning Y, Li S and Wang Z. Long non- coding RNA AFAP1-AS1 facilitates tumor growth and promotes metastasis in colorectal cancer. Biological research. 2016; 49:36.

72. Luo HL, Huang MD, Guo JN, Fan RH, Xia XT, He JD and Chen XF. AFAP1-AS1 is upregulated and promotes esophageal squamous cell carcinoma cell proliferation and inhibits cell apoptosis. Cancer medicine. 2016.

73. Li Q, Dai Y, Wang F and Hou S. Differentially expressed long non-coding RNAs and the prognostic potential in colorectal cancer. Neoplasma. 2016.

74. Li Z, Shen J, Chan MT and Wu WK. TUG1: a pivotal oncogenic long non-coding RNA of human cancers. Cell Prolif. 2016; 49:471-475.

75. Wang L, Zhao Z, Feng W, Ye Z, Dai W, Zhang C, Peng $\mathrm{J}$ and $\mathrm{Wu} \mathrm{K}$. Long non-coding RNA TUG1 promotes colorectal cancer metastasis via EMT pathway. Oncotarget. 2016; 7:51713-51719. doi: 10.18632/oncotarget.10563.

76. Zhai HY, Sui MH, Yu X, Qu Z, Hu JC, Sun HQ, Zheng HT, Zhou K and Jiang LX. Overexpression of Long Non-Coding RNA TUG1 Promotes Colon Cancer Progression. Med Sci Monit. 2016; 22:3281-3287.

77. Chen Z, He A, Wang D, Liu Y and Huang W. Long noncoding RNA HOTTIP as a novel predictor of lymph node metastasis and survival in human cancer: a systematic review and meta-analysis. Oncotarget. 2016; Oct 29. doi: 10.18632/oncotarget.12981. [Epub ahead of print]

78. Lian Y, Ding J, Zhang Z, Shi Y, Zhu Y, Li J, Peng P, Wang J, Fan Y, De W and Wang K. The long noncoding RNA HOXA transcript at the distal tip promotes colorectal cancer growth partially via silencing of p21 expression. Tumour Biol. 2016; 37:7431-7440.

79. Ren YK, Xiao Y, Wan XB, Zhao YZ, Li J, Li Y, Han GS, Chen XB, Zou QY, Wang GC, Lu CM, Xu YC and Wang YC. Association of long non-coding RNA HOTTIP with progression and prognosis in colorectal cancer. International journal of clinical and experimental pathology. 2015; 8:11458-11463.

80. Zhu L, Liu J, Ma S and Zhang S. Long Noncoding RNA MALAT-1 Can Predict Metastasis and a Poor Prognosis: a Meta-Analysis. Pathology oncology research : POR. 2015; 21:1259-1264.

81. Yang C, Li Z, Li Y, Xu R, Wang Y, Tian Y and Chen W. Long non-coding RNA NEAT1 overexpression is associated with poor prognosis in cancer patients: a systematic review and meta-analysis. Oncotarget. 2017; 8:2672-2680. doi: 10.18632/oncotarget.13737.

82. Huang G, Zhu H, Shi Y, Wu W, Cai H and Chen X. cirITCH plays an inhibitory role in colorectal cancer by regulating the Wnt/beta-catenin pathway. PloS one. 2015; 10:e0131225.

83. Karaconji T, Whist E, Francis IC and Ghabrial R. Re: "Intradioploic epidermoid cyst of frontal bone with spontaneous fistulization to eyelid". Ophthalmic plastic and reconstructive surgery. 2012; 28:230-231; author reply 231- 
232.

84. Zhou $\mathrm{T}$ and Gao Y. Increased expression of LncRNA BANCR and its prognostic significance in human hepatocellular carcinoma. World J Surg Oncol. 2016; 14:8.

85. Liu Z, Yang T, Xu Z and Cao X. Upregulation of the long non-coding RNA BANCR correlates with tumor progression and poor prognosis in esophageal squamous cell carcinoma. Biomed Pharmacother. 2016; 82:406-412.

86. Wang R, Du L, Yang X, Jiang X, Duan W, Yan S, Xie Y, Zhu Y, Wang Q, Wang L, Yang Y and Wang C. Identification of long noncoding RNAs as potential novel diagnosis and prognosis biomarkers in colorectal cancer. J Cancer Res Clin Oncol. 2016.

87. Guo Q, Zhao Y, Chen J, Hu J, Wang S, Zhang D and Sun Y. BRAF-activated long non-coding RNA contributes to colorectal cancer migration by inducing epithelialmesenchymal transition. Oncology letters. 2014; 8:869-875.

88. Shi Y, Liu Y, Wang J, Jie D, Yun T, Li W, Yan L, Wang K and Feng J. Downregulated Long Noncoding RNA BANCR Promotes the Proliferation of Colorectal Cancer Cells via Downregualtion of p21 Expression. PloS one. 2015; 10(4):e0122679.

89. Qu S, Yang X, Li X, Wang J, Gao Y, Shang R, Sun W, Dou $\mathrm{K}$ and Li H. Circular RNA: A new star of noncoding RNAs. Cancer letters. 2015; 365:141-148.

90. Qiu J, Chen Y, Huang G, Zhang Z, Chen L and Na N. The TGF-beta activated long non-coding RNA ATB plays an important role in acute rejection of renal allografts and may impacts the postoperative pharmaceutical immunosuppression therapy. Nephrology. 2016.

91. Ke L, Xu SB, Wang J, Jiang XL and Xu MQ. High expression of long non-coding RNA ATB indicates a poor prognosis and regulates cell proliferation and metastasis in non-small cell lung cancer. Clin Transl Oncol. 2016.

92. Ma CC, Xiong Z, Zhu GN, Wang C, Zong G, Wang HL, Bian EB and Zhao B. Long non-coding RNA ATB promotes glioma malignancy by negatively regulating miR200a. J Exp Clin Cancer Res. 2016; 35:90.

93. Iguchi T, Uchi R, Nambara S, Saito T, Komatsu H, Hirata H, Ueda M, Sakimura S, Takano Y, Kurashige J, Shinden Y, Eguchi H, Sugimachi K, Maehara Y and Mimori K. A long noncoding RNA, lncRNA-ATB, is involved in the progression and prognosis of colorectal cancer. Anticancer research. 2015; 35:1385-1388.

94. Yue B, Qiu S, Zhao S, Liu C, Zhang D, Yu F, Peng Z and Yan D. LncRNA-ATB mediated E-cadherin repression promotes the progression of colon cancer and predicts poor prognosis. Journal of gastroenterology and hepatology. 2016; 31:595-603.

95. Thorenoor N, Faltejskova-Vychytilova P, Hombach S, Mlcochova J, Kretz M, Svoboda M and Slaby O. Long noncoding RNA ZFAS1 interacts with CDK1 and is involved in p53-dependent cell cycle control and apoptosis in colorectal cancer. Oncotarget. 2016; 7:622-637. doi: 10.18632/ oncotarget.5807.

96. Nie F, Yu X, Huang M, Wang Y, Xie M, Ma H, Wang $\mathrm{Z}$, De $\mathrm{W}$ and Sun M. Long noncoding RNA ZFAS1 promotes gastric cancer cells proliferation by epigenetically repressing KLF2 and NKD2 expression. Oncotarget. 2016 May 26. doi: 10.18632/oncotarget.9611. [Epub ahead of print].

97. Li T, Xie J, Shen C, Cheng D, Shi Y, Wu Z, Deng X, Chen H, Shen B, Peng C, Li H, Zhan Q and Zhu Z. Amplification of Long Noncoding RNA ZFAS1 Promotes Metastasis in Hepatocellular Carcinoma. Cancer research. 2015; 75:31813191.

98. Wang W and Xing C. Upregulation of long noncoding RNA ZFAS1 predicts poor prognosis and prompts invasion and metastasis in colorectal cancer. Pathology, research and practice. 2016; 212:690-695.

99. Shen F, Cai WS, Feng Z, Chen JW, Feng JH, Liu QC, Fang YP, Li KP, Xiao HQ, Cao J and Xu B. Long non-coding RNA SPRY4-IT1 pormotes colorectal cancer metastasis by regulate epithelial-mesenchymal transition. Oncotarget. 2016 Jul 6. doi: 10.18632/oncotarget.10407. [Epub ahead of print].

100. Cao D, Ding Q, Yu W, Gao M and Wang Y. Long noncoding RNA SPRY4-IT1 promotes malignant development of colorectal cancer by targeting epithelialmesenchymal transition. Onco Targets Ther. 2016; 9:54175425.

101. Cao Y, Liu Y, Lu X, Wang Y, Qiao H and Liu M. Upregulation of long noncoding RNA SPRY4-IT1 correlates with tumor progression and poor prognosis in cervical cancer. FEBS open bio. 2016; 6:954-960.

102. Luo G, Wang M, Wu X, Tao D, Xiao X, Wang L, Min F, Zeng $F$ and Jiang G. Long Non-Coding RNA MEG3 Inhibits Cell Proliferation and Induces Apoptosis in Prostate Cancer. Cellular physiology and biochemistry. 2015; 37:2209-2220.

103. Liu LX, Deng W, Zhou XT, Chen RP, Xiang MQ, Guo YT, Pu ZJ, Li R, Wang GF and Wu LF. The mechanism of adenosine-mediated activation of lncRNA MEG3 and its antitumor effects in human hepatoma cells. Int J Oncol. 2016; 48:421-429.

104. Zhang J, Yao T, Wang Y, Yu J, Liu Y and Lin Z. Long noncoding RNA MEG3 is downregulated in cervical cancer and affects cell proliferation and apoptosis by regulating miR-21. Cancer biology \& therapy. 2016; 17:104-113.

105. Chang L, Wang G, Jia T, Zhang L, Li Y, Han Y, Zhang $\mathrm{K}$, Lin G, Zhang R, Li J and Wang L. Armored long non-coding RNA MEG3 targeting EGFR based on recombinant MS2 bacteriophage virus-like particles against hepatocellular carcinoma. Oncotarget. 2016; 7:2398824004. doi: 10.18632/oncotarget.8115.

106. Yin DD, Liu ZJ, Zhang E, Kong R, Zhang ZH and Guo RH. Decreased expression of long noncoding RNA MEG3 affects cell proliferation and predicts a poor prognosis 
in patients with colorectal cancer. Tumour Biol. 2015; 36:4851-4859.

107. Cao X, Zhuang S, Hu Y, Xi L, Deng L, Sheng H and Shen W. Associations between polymorphisms of long non-coding RNA MEG3 and risk of colorectal cancer in Chinese. Oncotarget. 2016; 7:19054-19059. doi: 10.18632/ oncotarget. 7764.

108. Kumegawa K, Maruyama R, Yamamoto E, Ashida M, Kitajima H, Tsuyada A, Niinuma T, Kai M, Yamano HO, Sugai T, Tokino T, Shinomura Y, Imai K and Suzuki H. A genomic screen for long noncoding RNA genes epigenetically silenced by aberrant DNA methylation in colorectal cancer. Sci Rep. 2016; 6:26699.

109. Taniue K, Kurimoto A, Sugimasa H, Nasu E, Takeda Y, Iwasaki K, Nagashima T, Okada-Hatakeyama M, Oyama M, Kozuka-Hata H, Hiyoshi M, Kitayama J, Negishi L, Kawasaki Y and Akiyama T. Long noncoding RNA UPAT promotes colon tumorigenesis by inhibiting degradation of UHRF1. Proceedings of the National Academy of Sciences of the United States of America. 2016; 113:1273-1278.

110. Wu X, He X, Li S, Xu X, Chen X and Zhu H. Long NonCoding RNA ucoo2kmd.1 Regulates CD44-Dependent Cell Growth by Competing for miR-211-3p in Colorectal Cancer. PloS one. 2016; 11:e0151287.

111. Zhang ZY, Lu YX, Zhang ZY, Chang YY, Zheng L, Yuan L, Zhang F, Hu YH, Zhang WJ and Li XN. Loss of TINCR expression promotes proliferation, metastasis through activating EpCAM cleavage in colorectal cancer. Oncotarget. 2016; 7:22639-22649. doi: 10.18632/ oncotarget.8141.

112. Liu S, Xu B and Yan D. Enhanced expression of long non-coding RNA Sox2ot promoted cell proliferation and motility in colorectal cancer. Minerva Med. 2016; 107:279286.

113. Yang L, Qiu M, Xu Y, Wang J, Zheng Y, Li M, Xu L and Yin R. Upregulation of long non-coding RNA PRNCR1 in colorectal cancer promotes cell proliferation and cell cycle progression. Oncol Rep. 2016; 35:318-324.

114. Chen H, Xu J, Hong J, Tang R, Zhang X and Fang JY. Long noncoding RNA profiles identify five distinct molecular subtypes of colorectal cancer with clinical relevance. Molecular oncology. 2014; 8:1393-1403.

115. Liu J, Wang J, Song Y, Yang Y, Hu Y, Gao P, Sun J, Chen $\mathrm{X}, \mathrm{Xu} \mathrm{Y}$ and Wang Z. A potential biomarker for colorectal cancer: long non-coding RNA RP1-13P20.6. Neoplasma. 2016; 63:984-990.

116. Lu M, Liu Z, Li B, Wang G, Li D and Zhu Y. The high expression of long non-coding RNA PANDAR indicates a poor prognosis for colorectal cancer and promotes metastasis by EMT pathway. J Cancer Res Clin Oncol. 2016.

117. Ge X, Chen Y, Liao X, Liu D, Li F, Ruan H and Jia W. Overexpression of long noncoding RNA PCAT-1 is a novel biomarker of poor prognosis in patients with colorectal cancer. Medical oncology. 2013; 30:588.

118. Qi P, Xu MD, Ni SJ, Shen XH, Wei P, Huang D, Tan C, Sheng WQ, Zhou XY and Du X. Down-regulation of ncRAN, a long non-coding RNA, contributes to colorectal cancer cell migration and invasion and predicts poor overall survival for colorectal cancer patients. Molecular carcinogenesis. 2015; 54:742-750.

119. Takahashi Y, Sawada G, Kurashige J, Uchi R, Matsumura T, Ueo H, Takano Y, Eguchi H, Sudo T, Sugimachi $\mathrm{K}$, Yamamoto $\mathrm{H}$, Doki $\mathrm{Y}$, Mori $\mathrm{M}$ and Mimori $\mathrm{K}$. Amplification of PVT-1 is involved in poor prognosis via apoptosis inhibition in colorectal cancers. British journal of cancer. 2014; 110:164-171.

120. Qi P, Xu MD, Ni SJ, Huang D, Wei P, Tan C, Zhou XY and $\mathrm{Du}$ X. Low expression of LOC285194 is associated with poor prognosis in colorectal cancer. Journal of translational medicine. 2013; 11:122.

121. Yan B, Gu W, Yang Z, Gu Z, Yue X, Gu Q and Liu L. Downregulation of a long noncoding RNA-ncRuPAR contributes to tumor inhibition in colorectal cancer. Tumour Biol. 2014; 35:11329-11335.

122. Ding J, Lu B, Wang J, Wang J, Shi Y, Lian Y, Zhu Y, Wang J, Fan Y, Wang Z, De W and Wang K. Long non-coding RNA Loc554202 induces apoptosis in colorectal cancer cells via the caspase cleavage cascades. J Exp Clin Cancer Res. 2015; 34:100.

123. Kazemzadeh M, Safaralizadeh R, Feizi MA, Ravanbakhsh R, Somi MH and Hashemzadeh S. LOC100287225, novel long intergenic non-coding RNA, misregulates in colorectal cancer. Cancer biomarkers : section A of Disease markers. 2016; 16:499-505.

124. Han D, Gao X, Wang M, Qiao Y, Xu Y, Yang J, Dong N, He J, Sun Q, Lv G, Xu C, Tao J and Ma N. Long noncoding RNA H19 indicates a poor prognosis of colorectal cancer and promotes tumor growth by recruiting and binding to eIF4A3. Oncotarget. 2016; 7:22159-22173. doi: 10.18632/ oncotarget.8063.

125. Bian Z, Jin L, Zhang J, Yin Y, Quan C, Hu Y, Feng Y, Liu H, Fei B, Mao Y, Zhou L, Qi X, Huang S, Hua D, Xing C and Huang Z. LncRNA-UCA1 enhances cell proliferation and 5-fluorouracil resistance in colorectal cancer by inhibiting miR-204-5p. Sci Rep. 2016; 6:23892.

126. Lee H, Kim C, Ku JL, Kim W, Yoon SK, Kuh HJ, Lee JH, Nam SW and Lee EK. A long non-coding RNA snaR contributes to 5-fluorouracil resistance in human colon cancer cells. Molecules and cells. 2014; 37:540-546.

127. Yue B, Cai D, Liu C, Fang C and Yan D. Linc00152 functions as a competing endogenous RNA to confer oxaliplatin resistance and holds prognostic values in colon cancer. Molecular therapy. 2016.

128. Ma Y, Yang Y, Wang F, Moyer MP, Wei Q, Zhang P, Yang Z, Liu W, Zhang H, Chen N, Wang H, Wang H and Qin H. Long non-coding RNA CCAL regulates colorectal cancer progression by activating Wnt/beta-catenin signalling 
pathway via suppression of activator protein 2 alpha. Gut. 2016; 65:1494-1504.

129. Wu KF, Liang WC, Feng L, Pang JX, Waye MM, Zhang JF and Fu WM. H19 mediates methotrexate resistance in colorectal cancer through activating Wnt/beta-catenin pathway. Exp Cell Res. 2016.

130. Wang G, Li Z, Zhao Q, Zhu Y, Zhao C, Li X, Ma Z, Li $\mathrm{X}$ and Zhang Y. LincRNA-p21 enhances the sensitivity of radiotherapy for human colorectal cancer by targeting the Wnt/beta-catenin signaling pathway. Oncol Rep. 2014; 31:1839-1845.

131. Yang XD, Xu HT, Xu XH, Ru G, Liu W, Zhu JJ, Wu YY, Zhao K, Wu Y, Xing CG, Zhang SY, Cao JP and Li M. Knockdown of long non-coding RNA HOTAIR inhibits proliferation and invasiveness and improves radiosensitivity in colorectal cancer. Oncol Rep. 2016; 35:479-487.

132. Zhang J, Tian XJ and Xing J. Signal Transduction Pathways of EMT Induced by TGF-beta, SHH, and WNT and Their Crosstalks. J Clin Med. 2016; 5.

133. Lamouille S, Xu J and Derynck R. Molecular mechanisms of epithelial-mesenchymal transition. Nat Rev Mol Cell Biol. 2014; 15:178-196.

134. Zhang Z, Zhou C, Chang Y, Zhang Z, Hu Y, Zhang F, Lu Y, Zheng L, Zhang W, Li X and Li X. Long non-coding RNA CASC11 interacts with hnRNP-K and activates the WNT/ beta-catenin pathway to promote growth and metastasis in colorectal cancer. Cancer letters. 2016; 376:62-73.

135. Yuan Z, Yu X, Ni B, Chen D, Yang Z, Huang J, Wang J,
Chen D and Wang L. Overexpression of long non-coding RNA-CTD903 inhibits colorectal cancer invasion and migration by repressing Wnt/beta-catenin signaling and predicts favorable prognosis. Int J Oncol. 2016; 48:26752685.

136. Brabletz T, Jung A, Reu S, Porzner M, Hlubek F, KunzSchughart LA, Knuechel R and Kirchner T. Variable betacatenin expression in colorectal cancers indicates tumor progression driven by the tumor environment. Proceedings of the National Academy of Sciences of the United States of America. 2001; 98:10356-10361.

137. Yue B, Sun B, Liu C, Zhao S, Zhang D, Yu F and Yan D. Long non-coding RNA Fer-1-like protein 4 suppresses oncogenesis and exhibits prognostic value by associating with miR-106a-5p in colon cancer. Cancer science. 2015; 106:1323-1332.

138. Wang L, Bu P, Ai Y, Srinivasan T, Chen HJ, Xiang K, Lipkin SM and Shen X. A long non-coding RNA targets microRNA miR-34a to regulate colon cancer stem cell asymmetric division. eLife. 2016; 5.

139. Chen X, Zhu H, Wu X, Xie X, Huang G, Xu X, Li S and Xing C. Downregulated pseudogene CTNNAP1 promote tumor growth in human cancer by downregulating its cognate gene CTNNA1 expression. Oncotarget. 2016; 7:55518-55528. doi: 10.18632/oncotarget.10833. 